\title{
POMOC PSYCHOLOGICZNA RODZINOM W KRYZYSIE - SPECYFIKA WSPARCIA W OSTRYM I PRZEWLEKLYM STRESIE
}

\begin{abstract}
Streszczenie
Istotą kryzysu jest zakłócenie dotychczasowej równowagi psychicznej. Sytuacja narażenia na ostry stres o dużm natężeniu lub stres przewlekty $i$ dlugotrwaty zwiazana jest z poczuciem, że dotychczasowe zasoby i możliwości radzenia sobie sa niewystarczające. W efekcie najczęściej pojawia się intensywna reakcja emocjonalna uniemożliwiająca zadaniowe podejście do problemu. Wśród wydarzeń krytycznych szczególne miejsce zajmuja te o ekstremalnym nasileniu, zwane zdarzeniami traumatycznymi. Najczęściej sq one związane z narażeniem na sytuacje zagrożenia życia, zachorowaniem lub ryzykiem poważnego urazu.

Artykut ma na celu przedstawienie specyfiki pracy psychologicznej z rodzina $w$ ostrym $i$ dlugotrwałym stresie $z$ uwzględnieniem różnic $i$ podobieństw $w$ charakterystykach tych rodzin. Rozważania będa stanowić pogłębiona analize literatury przedmiotu oraz wnioski wynikajace z pracy z rodzinami $w$ warunkach przeżywania kryzysu związanego z zachorowaniem bliskiej osoby (Oddziat Anestezjologii i Intensywnej Terapii Szpitala Uniwersyteckiego w Krakowie oraz Oddział Rehabilitacji Neurologicznej Szpitala Św. Rafała w Krakowie).
\end{abstract}

Słowa klucze: interwencja kryzysowa, pomoc psychologiczna, reakcja na stres, rodzina w kryzysie, trauma

* Donata Liberacka - Klinika Intensywnej Terapii Interdyscyplinarnej; Uniwersytet Jagielloński Collegium Medicum O/K Anestezjologii i Intensywnej Terapii nr 1; Szpital Uniwersytecki w Krakowie Oddział Rehabilitacji Neurologicznej; Szpital Św. Rafała w Krakowie. 


\section{Istota kryzysu, wprowadzenie}

Piśmiennictwo poświęcone zagadnieniu kryzysu wciąż nie dostarcza powszechnie akceptowalnej jego definicji1. W słownikowej definicji kryzys emocjonalny jest stanem pewnej nierównowagi psychicznej, który ma znaczenie przełomowe. Jest punktem zwrotnym życia, który wymaga natychmiastowych rozwiązań. Dotyczy przy tym najistotniejszych kwestii, takich jak stan zdrowia człowieka, jego relacji z otoczeniem, konieczność wyznaczenia kierunku czy sensu dalszego życia ${ }^{2}$. Kryzys emocjonalny może stanowić adekwatną reakcję na wydarzenia krytyczne, zwłaszcza te niespotykane i niespodziewane, wobec których niewystarczające okazują się dotychczasowe zasoby i sposoby radzenia sobie. W przeżyciu osoby będącej w kryzysie dochodzi niejednokrotnie do zupełnego rozpadu wizji świata jako miejsca bezpiecznego i przewidywalnego. Pojawiają się regresywne tendencje, z wyzwoleniem dziecięcych lęków oraz życzeń, nierzadko z potrzebą bycia chronienia lub wspomagania przez rodzicielską figurę - zwłaszcza w kontekście integrowania trudnego doświadczenia, nadawania mu znaczenia.

W literaturze przedmiotu nierzadko pojawia się nacisk na potrzebę systemowego podejścia w interwencji kryzysowej, który obejmuje wielostronną i wieloaspektową pomoc w kryzysie ${ }^{3}$. W kryzysie zachodzi konieczność udzielenia kompleksowej pomocy z udziałem zespołu specjalistów reprezentujących różne profesje - najczęściej medyczną, prawną, socjalną oraz psychologiczną. Interdyscyplinarność dotyczy nie tylko wielości specjalizacji wchodzących w skład zespołu pomagającego, podkreśla również złożoność kompetencji charakteryzujących interwentów. W pracy z kryzysem zarówno lekarz, pielęgniarka, jak i pracownik socjalny postawieni zostają w sytuacji, w której wymaga się od nich pewnych kompetencji psychologicznych. W odniesieniu do pracy socjalnej literatura wskazuje wręcz na dwa istotne rodzaje relacji pomocowej: relację powierniczą oraz relację terapeutyczną ${ }^{4}$.

Przy ustanawianiu typologii kryzysów bierze się pod uwagę zarówno kryteria formalne, jak i treściowe. Jednym z podziałów uwzględniających kryteria formalne jest przeciwstawianie sobie kryzysów ostrych oraz tych, które narastają powoli lub

\footnotetext{
1 D. Kubacka-Jasiecka, M.Ziarko, Pomoc psychologiczna w różnych typach kryzysu, w: Psychologia kliniczna, red. L.Cierpiałkowska, H. Sęk, PWN, Warszawa 2016, s. 675-694.

2 R.K. James, B.E. Gilliland, Theories and strategies in counseling and psychotherapy, Pearson Education, Boston 2004.

3 D. Kubacka-Jasiecka, Interwencja kryzysowa. Pomoc w kryzysach psychologicznych, WAiP, Warszawa 2010.

4 R. Johner, Dual relationship legitimization and client self-determination, "Journal of social work values and ethics" 2006, Volume 3, Nr 1.
} 
występują w przebiegu stresu długotrwałego ${ }^{5}$. Ważnym dla dalszej dyskusji jest również wskazanie istnienia kryzysów sytuacyjnych i traumatycznych, których człowiek nie potrafi przewidzieć czy kontrolować. W związku z powyższym najczęściej towarzyszy im nasilone poczucie szoku, utraty oraz krzywdy.

Dalsze rozważania będą stanowić pogłębioną analizę literatury przedmiotu oraz wnioski z pracy z rodzinami przeżywającymi kryzys wynikający z zachorowania bliskiej osoby. Rodziny te zostały objęte opieką psychologiczną w ramach współpracy z Oddziałem Anestezjologii i Intensywnej Terapii Szpitala Uniwersyteckiego w Krakowie oraz Oddziałem Rehabilitacji Neurologicznej Szpitala Św. Rafała w Krakowie. Celem pracy jest przedstawienie specyfiki pracy psychologicznej $\mathrm{z}$ rodziną $\mathrm{w}$ ostrym i przewlekłym stresie $\mathrm{z}$ uwzględnieniem różnic i podobieństw w charakterystykach tych rodzin.

\section{Kryzys zdrowotny}

Ciężka choroba somatyczna - własna lub osoby najbliższej - stanowi jedną $\mathrm{z}$ istotniejszych przyczyn kryzysu emocjonalnego. Dla tego typu sytuacji charakterystyczne są silne emocje związane z zagrożeniem życia i zdrowia, wynikające przede wszystkim z poczucia niepewności, bezradności, braku kontroli. Osoby doświadczające kryzysu nierzadko wskazują na poczucie szoku, odrętwienia i zakleszczenia, zablokowania myślenia oraz zamknięcia perspektywy przyszłości. Dodatkowo pojawia się poczucie bycia osamotnionym lub wręcz opuszczonym - najczęściej w związku z brakiem możliwości doświadczenia jakiejkolwiek ulgi, zdystansowania się i odpoczynku od tego, co się przeżywa. Negatywne konsekwencje poważnego kryzysu zdrowotnego obejmują zarówno dokonywanie ujemnego bilansu życiowego ${ }^{6}$ jak i dekompensacje, które mogą przejawiać się w zaburzeniach sfery emocjonalnej, neurotyzacji lub rozpadzie osobowości w postaci utraty poczucia własnej tożsamości i wartości.

Choroba somatyczna jest sytuacją krytyczną dla chorego i całej jego rodziny, wpływa na strukturę rodziny oraz role przyjmowane przez poszczególnych jej członków ${ }^{8}$. Trudne do pomieszczenia, nierzadko przeciwstawne sobie stany

\footnotetext{
5 D.Kubacka-Jasiecka, M. Ziarko, Pomoc psychologiczna w różnych typach kryzysu, w: Psychologia kliniczna, red. L. Cierpiałkowska, H. Sęk, PWN, Warszawa 2016, s. 675-694.

6 I. Heszen-Klemens, Poznawcze uwarunkowania zachowania się wobec własnej choroby, Ossolineum, Wrocław 1979.

7 I. Heszen-Niejodek (red.), Doświadczenie kryzysu - szansa rozwoju czy ryzyko zaburzeń, Wyd. Uniwersytetu Śląskiego, Katowice 1995.

8 S. Kowalik, Psychologia rehabilitacji, WAiP, Warszawa 2007.
} 
wewnętrzne - takie jak chociażby poczucie utraty kontroli z nasileniem poczucia odpowiedzialności, chęci walki o bliskiego - przyczyniają się do wtórnych zaburzeń w systemie rodzinnym. Wcześniejsze dysfunkcje i trudności mogą się nasilić, zaburzając możliwość komunikacji nie tylko wewnątrz rodziny, ale i na zewnątrz - ze specjalistami, osobami próbującymi pomóc. Wyniki badań potwierdzają, że zwłaszcza deficyty obejmujące zdolności empatyczne i komunikacyjne przyczyniają się do pojawienia się kolejnych zaburzeń - o charakterze depresji, chronicznego stresu czy wypalenia9. Wciąż nie jest do końca znany wpływ rodziny na funkcjonowanie chorego. Wskazuje się zarówno na pozytywne oddziaływanie bliskich na pacjenta poprzez konkretne formy wsparcia ${ }^{10}$, jak i samą obecność drugiej osoby - fakt posiadania partnera ${ }^{11}$. Istnieją doniesienia podkreślające istnienie $\mathrm{w}$ rodzinie zarówno potencjału sprzyjającego, jak i hamującego proces odzyskiwania zdrowia ${ }^{12}$. Zaburzający wpływ rodziny wynika najczęściej z nadopiekuńczości ${ }^{13}$. Warto podkreślić, że w reakcji na zachorowanie zarówno pacjent, jak i jego rodzina przechodzą przez długi i skomplikowany proces adaptacji, w którym muszą pogodzić się z pewną utratą - wizji siebie lub bliskiego, planów na teraźniejszość lub przyszłość, poczucia bezpieczeństwa i przewidywalności. $\mathrm{W}$ literaturze porównuje się ten proces do pracy z żałobą, z wszystkimi jej charakterystycznymi fazami przystosowania ${ }^{14}$. Co ciekawe, współczesne badania

9 M. Sutter, P.B. Perrin, Y. Chang, G.R. Hoyos, J.A. Buraye, J.C. Arango-Lasprilla, Linking family dynamics and the mental health of Colombian Dementia Caregivers, "American Journal of Alzheimer's Disease and Other Dementias" 2014, nr 29(1), s. 67-75.

10 P. Lowe, K. McBride-Henry, What factors impact upon the quality of life of elderly women with chronic illnesses: Three women's perspectives, "Contemporary Nurse" 2012, nr 41(1), s.18-27.

${ }^{11}$ M.H.Chung, N. Hsu, Y.C. Wang, K.L. Lai, S. Kao, Exploration into the variance in self-reported health-related quality of life between the chronically-ill elderly and their family caregivers, "The Journal Of Nursing Research" 2007, nr 15 (3), s. 175-82.

12 A. Reupert, D. Maybery, M. Cox, E. Scott Stokes, Place of family in recovery models for those with a mental illness, "International Journal of Mental Health Nursing" 2015.

13 N. Maclean, P. Pound, C. Wolfe, A. Rudd, Qualitative analysis of stroke patients' motivation for rehabilitation, "British Medical Association" 2000, nr 321(7268), s. 1051-1054. lub zaprzeczania dysfunkcjom L. Miller, The ,other' brain injuries: Psychotherapeutic issues with stroke and brain tumor patients, "Cognitive Rehabilitation" 1991, nr 9(5), s. 10-16).

14 R. Rokkaku, Support for families with a family member suffering a cognitive disorder, "Psychogeriatrics" 2007, nr 7(3), s. 144-146. 
wskazują, że oddziaływania nakierowane na redukcję depresji u najbliższych członków rodziny wiążą się z istotną redukcją depresji u pacjenta chorującego somatycznie ${ }^{15}$.

W zmaganiu się z kryzysem zdrowotnym niezwykle istotną wartość adaptacyjną stanowi możliwość redukowania lęku i niepokoju. Badacze problemu wskazują na korzyści mogące wynikać z uruchomienia mechanizmów obronnych w sytuacji trudnej, zwłaszcza w pierwszej fazie reakcji kryzysowej (mają one wtedy służyć zdystansowaniu się, ,złapaniu oddechu”) oraz w końcowym etapie, kiedy wyczerpaniu ulegają dostępne środki i zasoby ${ }^{16}$. Oczywiście, procesy te mogą również powodować ewidentne straty i szkody, jednak ich ostateczna ocena powinna być zawsze dokonywana z uwzględnieniem szerszego kontekstu, czynników indywidualnych. Zgodnie z koncepcją adaptacji poznawczej Taylor u osób zmagających się z kryzysem istnieje silna potrzeba poszukiwania znaczenia i sensu wydarzeń zagrażających, zdobywania poczucia kontroli oraz odzyskiwania zachwianego poczucia wartości „Ja"17.

\section{Wsparcie w ostrym stresie}

Kontakt z rodziną będącą w ostrym stresie jest szczególnie trudnym doświadczeniem dla każdego specjalisty. Istotą traumy jest fakt, że przytłacza ona osobę doświadczającą - załamując normalny sposób myślenia i reagowania, zdolność do rozsądnego działania oraz rozumowania. Ofiara tego wydarzenia szuka więc pomocy, by przynajmniej częściowo odzyskać równowagę. Udzielając pomocy należy więc oscylować pomiędzy otwartością na przeżycia pacjenta - w celu zrozumienia jego stanu oraz zrównoważeniem - by siła przeżyć nie odebrała możliwości myślenia ${ }^{18}$. Odnalezienie równowagi pomiędzy tymi stanami skutkuje ostatecznie zdolnością pomieszczania, które przynosi ulgę osobie będącej w kryzysie.

15 K.D. Vallury, M. Jones, R. Gray, Do family-oriented interventions reduce poststroke depression? A systematic review and recommendations for practice, "Topics In Stroke Rehabilitation" 2015, s. 107-149.

16 C.B. Wortman, R.C. Silver, The myths of coping with loss, "Journal of Consulting and Clinical Psychology"1989, nr 57(3), s.349-357.

17 S.E. Taylor, R.R. Lichtman, J.W. Wood, Attributions, beliefs about control, and adjustment to breast cancer, "Journal of Personality and Social Psychology” 1984, nr 46(3), s. 489-502.

18 C. Garland, Jak myśleć o traumie? w: Czym jest trauma? Podejście psychoanalityczne, red. C. Garland, Oficyna Ingenium, Warszawa 2013, s. 19-41. 
W pracy z rodziną doświadczającą ostrego stresu istotnym jest włączenie oddziaływań nakierowanych na przywrócenie utraconego poczucia bezpieczeństwa i równowagi psychicznej. Sprzyja temu wzmocnienie struktury i przewidywalności poprzez wskazanie pewnych reguł i zasad oraz bieżące informowanie o tym, co się dzieje. Bardzo często emocje, które wydają się nie do opanowania udaje się skontrolować poprzez próby nazywania i normalizowania reakcji, bez podkreślania konieczności uspokojenia czy wyciszenia się. Dodatkowo, kontakt ma służyć ułatwieniu realistycznej percepcji kryzysu, jego wstępną akceptację - uznanie, że „(...) to wydarzyło się naprawdę". W wielu sytuacjach podejmuje się próby dyskutowania z częścią mechanizmów obronnych bez ich forsowania, poprzez szukanie wątpliwości w systemie zaprzeczeń („Czy są momenty, w których czuje/myśli Pan inaczej?”). Przed przekazywaniem informacji trudnych warto również zapoznać się z obecnymi w literaturze algorytmami postępowania obejmującymi zarówno wytyczne organizacyjne, jak i wzmacniającymi kompetencje komunikacyjne oraz emocjonalne ${ }^{19}$. Ulgę może przynieść przy tym określenie utraty - tego, czego ona dotyczy, a tym samym zainicjowanie pracy żałoby - wysiłku na rzecz wycofania emocji oraz osłabienia więzi łączących jednostkę nie tylko z utraconymi osobami, ale i z pożądanymi aspektami życia, wizją siebie lub bliskiego jako zdrowego, pełnego sił. W kontakcie z osobami będącymi w ostrym kryzysie istotnym jest włączanie lub uruchamianie sieci wsparcia we własnym środowisku, łączenie członków rodziny w koalicje służące rozwiązywaniu problemu - co może przyczynić się do późniejszego wzmocnienia relacji. Badacze zespołu ostrego stresu wskazują przy tym na konieczność chwilowego wstrzymania się z interwencją profesjonalną, a przez to ukierunkowanie na aktywizację i mobilizację rodzinnych zasobów zmagania się z kryzysem ${ }^{20}$.

\section{Wsparcie w kryzysie długotrwałym}

Istotą kryzysu długotrwałego - takiego jak kryzys choroby przewlekłej - jest fakt, że utrzymuje się on przez dłuższy okres czasu. Skutkiem tego może być nasilanie i kumulowanie negatywnych następstw obejmujących różne aspekty życia osoby chorej i jej rodziny. Potencjalne trudności wynikające z choroby przewlekłej

19 J. Lickiewicz, W. Serednicki, E. Zasada, J. Wordliczek, Wprowadzenie algorytmu postępowania i kontaktu z rodzina pacjenta krytycznie chorego. Doświadczenie Centrum Urazowego Medycyny Ratunkowej i Katastrof w Krakowie, „Anestezjologia i Ratownictwo” 2014, nr 8, s. 441-447.

20 R.A. Bryant, A.G. Harvey, Terapia zespołu ostrego stresu w: Zespół ostrego stresu, R.A. Bryant, A.G. Harvey, PWN, Warszawa 2012, s. 85-121. 
dotyczą obszaru biologicznego (niepełnosprawność, oszpecenia), psychologicznego (doświadczenie cierpienia, zahamowanie w rozwoju, negatywne stany emocjonalne), społecznego (zmiany w obrębie ról społecznych), behawioralnego (wzorce aktywności, poddawanie się procedurom medycznym) oraz środowiskowego (sytuacja materialna) ${ }^{21}$.

W literaturze dotyczącej stresu chronicznego bardzo często analizowane są czynniki ryzyka wystąpienia poważnych zespołów psychopatologicznych w postaci zespołu przewlekłego zmęczenia ${ }^{22}$. Długotrwała sytuacja kryzysowa może też wiązać się z pogorszeniem zdrowia fizycznego - badania wskazują, że u opiekunów pacjentów chorujących na Chorobę Alzheimera obserwuje się zaburzenia układu sercowo- naczyniowego oraz immunologicznego $0^{23}$.

Istnieje bardzo mało doniesień dotyczących możliwości pomocy psychologicznej osobom będącym w długotrwałym kryzysie. Autorzy wskazują, że celowe jest wypracowanie specyficznych - niezbędnych do przezwyciężenia kryzysu choroby przewlekłej - form radzenia sobie, takich jak radzenie skoncentrowane na znaczeniu ${ }^{24}$. Zmaganie się z przewlekłym stresem często wiąże się z bolesnym poczuciem niesprawiedliwości i bezsensu, osamotnienia oraz złości na los. Wydaje się, że są to tematy, które powinny wybrzmieć w trakcie rozmów ze specjalistami, poruszające i integrujące pomimo braku realnych odpowiedzi na stawiane pytania. W pracy z długotrwałym kryzysem ważne są przy tym wszelkie oddziaływania mające osadzenie $\mathrm{w}$ realności, obejmujące chociażby psychoedukację czy grupy wsparcia. Istotna wydaje się być również dalsza praca podtrzymująca nakierowana na wzmocnienie procesu adaptacji do sytuacji trudnej.

21 M. Ziarko, Zmaganie się ze stresem choroby przewlekłej, Wydawnictwo Naukowe Wydziału Nauk Społecznych UAM, Poznań 2014.

22 G. Chojnacka-Szwałowska, Zmęczenie a zdrowie i choroba (perspektywa psychologiczna), Oficyna Wydawnicza „Impuls”, Kraków 2009, depresji czy zaburzeń lękowych A. Witusik, T. Pietras, Lęk i depresja u opiekunów osób chorych na otępienie - badania pilotażowe, „Psychogeriatria Polska” 2007, nr 4(1), s. 1-6.

23 I. Kłoszewska, Rola opiekuna chorych z otępieniem, „Polski Przegląd Neurologiczny” 2007, nr 2, s. 105-109.

24 S. Folkman, J. Moskowitz, Coping: Pitfalls and promise, "Annual Review of Psychology" 2004, nr 55, s. 745-774 oraz porównania społeczne V.J. Derlega, I. Robinett, B.A. Winstead, G.M. Saadeh, Psychological impast of comparing oneself to Rother persons with diabetes, "Journal of loss and trauma" 2005, nr 10(3), s. 293-311. 


\section{Specyfika wsparcia w ostrym i przewlekłym stresie}

Z dotychczasowych rozważań wyłaniają się wstępne różnice i podobieństwa $\mathrm{w}$ charakterystykach rodzin będących w ostrym i przewlekłym kryzysie oraz w specyfice oddziaływań psychologicznych, jakimi są one objęte.

Kryzys ostry często wiąże się z ekstremalnymi stanami emocjonalnymi, wahającymi się od rozpaczy, złości przez pobudzenie do totalnego ,zmrożenia i osłupienia". W długotrwałym kryzysie emocje są już słabiej obserwowalne, cała energia jest koncentrowana na zadaniu, jakim jest przetrwanie, walka o poprawę lub utrzymanie status quo. Emocje ukryte są pod ogólnym terminem „bycia zmęczonym/niewystarczająco dobrym". W czasie trwania choroby somatycznej zmieniają się emocje wobec osoby hospitalizowanej - w ostrym stresie rodzina najczęściej idealizuje bliskiego, budzi on pozytywne emocje pomieszane ze współczuciem. W długotrwałym kryzysie pojawia się złość, niechęć i frustracja w związku z brakiem poprawy lub pogarszaniem się stanu bliskiego oraz własnym zmęczeniem. Emocje te zazwyczaj obciążone są silnym poczuciem winy. Zdarza się, że rodzina jest tak silnie obarczona własnymi powinnościami wobec bliskiego, że nie dopuszcza żadnej innej osoby czy instytucji do pomocy w opiece - inicjując tym samym swoiste błędne koło zmęczenia i negatywnych emocji wobec siebie, chorego i świata. Inaczej zresztą wydaje się wyglądać dostępność wsparcia społecznego w przypadku kryzysu ostrego i długotrwałego. Choć nie istnieje tu żadna prosta zależność, najbliższe otoczenie zazwyczaj organizuje pomoc wtedy, gdy wydaje się ona najpotrzebniejsza - czyli w fazie ostrej.

W pracy psychologicznej ważnym wydaje się być uznanie trudu i strat obejmujących zarówno kryzys ostry, jak i przewlekły. W związku z obecnością silnych emocji istotne jest nazywanie przeżyć i łączenie ich z doświadczaniem, normalizowanie pewnych stanów i odkrywanie bezzasadności innych. Kryzys ostry wiąże się oddziaływaniami charakterystycznymi dla interwencji kryzysowej, podczas gdy w stresie długotrwałym ważniejsza wydaje się dalsza praca integrującą i podtrzymująca, wraz z psychoedukacją. Celem wsparcia w nagłym kryzysie jest przede wszystkim mobilizacja zasobów, zarówno tych wewnętrznych, jak i zewnętrznych, towarzyszenie i pomoc w zniesieniu tego, co najtrudniejsze. W sytuacji przewlekłej ważne wydaje się natomiast kontynuowanie tej pracy poprzez szukanie i nadawanie znaczenia. 


\title{
Donata Liberacka: Psychological help to families in crisis - the support in acute and chronic stress associated with somatic illness
}

\begin{abstract}
Summary
The essence of the crisis is the disruption of the psychological balance. Exposure to acute stress of high intensity or severe and chronic stress is associated with the feeling that our resources and coping abilities are insufficient. As a result, a strong emotional reaction forecloses a task-oriented approach to the problem. Traumas are critical events of extreme severity. They are often connected with exposure to life-threatening situations, illness or serious injury.

The purpose of the article is to present the specifics of the psychological work with the family in acute and chronic stress indicating the differences and similarities in the characteristics of these families. Considerations are based on an analysis of the literature and conclusions from work with families experiencing a crisis because of the disease of a loved one. These families were receiving psychological support in the Department of Anesthesiology and Intensive Care of the University Hospital in Cracow and in the Rehabilitation Center of the St. Raphael Hospital in Cracow.
\end{abstract}

Key words: crisis intervention, psychological help, reaction to stress, family in crisis, trauma

\section{Bibliografia}

R. A. Bryant, A.G. Harvey, Terapia zespołu ostrego stresu w: Zespół ostrego stresu, R.A. Bryant, A.G. Harvey, PWN, Warszawa 2012, s. 85-121.

G. Chojnacka-Szwałowska, Zmęczenie a zdrowie i choroba (perspektywa psychologiczna), Oficyna Wydawnicza „Impuls”, Kraków 2009.

M.H.Chung, N. Hsu, Y.C. Wang, K.L. Lai, S. Kao, Exploration into the variance in self-reported health-related quality of life between the chronically-ill elderly and their family caregivers, "The Journal Of Nursing Research" 2007, nr 15 (3), s. 175-82.

V.J. Derlega, I. Robinett, B.A. Winstead, G.M. Saadeh, Psychological impast of comparing oneself to Rother persons with diabetes, "Journal of loss and trauma" 2005, nr 10(3), s. 293-311.

S. Folkman, J. Moskowitz, Coping: Pitfalls and promise, "Annual Review of Psychology" 2004, nr 55, s. 745-774.

C. Garland, Jak myśleć o traumie? w: Czym jest trauma? Podejście psychoanalityczne, red. C. Garland, Oficyna Ingenium, Warszawa 2013, s. 19-41. 
I. Heszen-Klemens, Poznawcze uwarunkowania zachowania się wobec własnej choroby, Ossolineum, Wrocław 1979.

I. Heszen-Niejodek (red.), Doświadczenie kryzysu - szansa rozwoju czy ryzyko zaburzeń, Wyd. Uniwersytetu Śląskiego, Katowice 1995.

James R.K., Gilliland B.E., Theories and strategies in counseling and psychotherapy, Pearson Education, Boston 2004.

R. Johner, Dual relationship legitimization and client self-determination, "Journal of social work values and ethics" 2006, Volume 3, Nr 1.

I. Kłoszewska, Rola opiekuna chorych z otępieniem, „Polski Przegląd Neurologiczny" 2007, nr 2, s. 105-109.

S. Kowalik, Psychologia rehabilitacji, WAiP, Warszawa 2007.

D. Kubacka-Jasiecka, Interwencja kryzysowa. Pomoc w kryzysach psychologicznych, WAiP, Warszawa 2010.

D. Kubacka-Jasiecka, M.Ziarko, Pomoc psychologiczna w różnych typach kryzysu, w: Psychologia kliniczna, red. L.Cierpiałkowska, H. Sęk, PWN, Warszawa 2016, s. 675-694.

J. Lickiewicz, W. Serednicki, E. Zasada, J. Wordliczek, Wprowadzenie algorytmu postępowania i kontaktu z rodzina pacjenta krytycznie chorego. Doświadczenie Centrum Urazowego Medycyny Ratunkowej i Katastrof $w$ Krakowie, „Anestezjologia i Ratownictwo" 2014, nr 8, s. 441-447.

P. Lowe, K. McBride-Henry, What factors impact upon the quality of life of elderly women with chronic illnesses: Three women's perspectives, "Contemporary Nurse" 2012, nr 41(1), s. 18-27.

N. Maclean, P. Pound, C. Wolfe, A. Rudd, Qualitative analysis of stroke patients' motivation for rehabilitation, "British Medical Association" 2000, nr 321(7268), s. 1051-1054.

L. Miller, The ,other' brain injuries: Psychotherapeutic issues with stroke and brain tumor patients, "Cognitive Rehabilitation" 1991, nr 9(5), s. 10-16.

A. Reupert, D. Maybery, M. Cox, E. Scott Stokes, Place of family in recovery models for those with a mental illness, "International Journal of Mental Health Nursing” 2015.

R. Rokkaku, Support for families with a family member suffering a cognitive disorder, "Psychogeriatrics" 2007, nr 7(3), s. 144-146.

M. Sutter, P.B. Perrin, Y. Chang, G.R. Hoyos, J.A. Buraye, J.C. Arango-Lasprilla, Linking family dynamics and the mental health of Colombian Dementia Caregivers, "American Journal of Alzheimer's Disease and Other Dementias" 2014, nr 29(1), s. 67-75. 
S.E. Taylor, R.R. Lichtman, J.W. Wood, Attributions, beliefs about control, and adjustment to breast cancer, "Journal of Personality and Social Psychology" 1984, nr 46(3), 489-502.

A. Witusik, T. Pietras, Lęk i depresja u opiekunów osób chorych na otępieniebadania pilotażowe, „Psychogeriatria Polska” 2007, nr 4(1), s. 1-6.

C.B. Wortman, R.C. Silver, The myths of coping with loss, "Journal of Consulting and Clinical Psychology" 1989, nr 57(3), s. 349-357.

K.D. Vallury, M. Jones, R. Gray, Do family-oriented interventions reduce poststroke depression? A systematic review and recommendations for practice, "Topics In Stroke Rehabilitation" 2015, s. 107-149.

M. Ziarko, Zmaganie się ze stresem choroby przewlektej, Wydawnictwo Naukowe Wydziału Nauk Społecznych UAM, Poznań 2014. 